The US Anti-Prostitution Pledge:

\section{A Call for Cooperation}

\section{Jay Silverman, Michele Decker}

Masenior and Beyrer's article is an important contribution to the continuing debate as to the direction of public health efforts regarding commercial sex work [1]. The authors are correct in that the debate between those focused on the social and economic rights of prostituted women and girls as "workers" and those focused on preventing the trafficking of women and girls into prostitution has resulted in precious little dialogue on how to best proceed.

Regrettably, as illustrated by the authors, the US antiprostitution pledge may well have contributed to the polarization of these two groups. However, to make progress, multiple realities must be acknowledged and considered. The authors present the conflation of sex trafficking and prostitution as a barrier to effective action and policy that must be eliminated; however, compelling evidence exists to support such conflation.

Specifically, approximately half of sex workers are prostituted as minors [2,3]. Studies including prostituted minors indicate that virtually all were trafficked into sex work [4], and studies of sex workers across multiple countries indicate that the majority would prefer to leave prostitution if it were safe and economically feasible to do so $[2,5]$. Thus, anti-trafficking advocates may reasonably contend that maintaining the institution of sex work through decriminalization and organization of health and social welfare programs will likely lead to continued trafficking of women and girls to maintain this highly profitable activity.

On the other hand, as presented by Masenior and Beyrer, the many thousands of women and girls involved in commercial sex work need and deserve assistance based on the tremendous health risks they suffer (e.g., HIV infection). However, those focused on promoting the health of sex workers have often inadequately considered the presence of minor girls [6] or trafficking victims in the sex work venues within which they operate [7]. While such programs appear to empower adults purporting to be engaged in voluntary sex work, no evidence suggests that these efforts contribute to reducing the numbers or protecting the health of trafficked women and girls.

While we cannot reasonably make the assumption that all sex workers are trafficked, we also cannot reasonably accept that all sex workers are voluntarily prostituted. Amazingly, we have yet to conduct adequate research to answer this question. Thus the conflation of sex work and trafficking continues, as lamented by the authors. To move forward, both sides must work together based on their common goal of improving the health and well-being of this highly vulnerable population. Advocates, practitioners, and researchers representing both sides of this debate must dialogue to find effective means of reducing trafficking of women and girls for sexual exploitation, and also to find ways to assist sex workers to minimize the health risks they face, while simultaneously remaining vigilant in detecting and humanely assisting prostituted children and adult trafficking victims.
Jay Silverman (jsilverm@hsph.harvard.edu)

\section{Michele R. Decker}

Harvard School of Public Health

Boston, Massachusetts, United States of America

\section{References}

1. Masenior NF, Beyrer C (2007) The US anti-prostitution pledge: First Amendment challenges and public health priorities. PLoS Med 4: e207. doi:10.1371/journal.pmed.0040207

2. Farley M, Cotton A, Lynne J, Zumbeck S, Spiwak F, et al. (2003) Prostitution and trafficking in nine countries: An update on violence and posttraumatic stress disorder. J Trauma Pract 2: 33-74.

3. Nair PM (2004) A report on trafficking of women and children in India: 2002-2003. Volume I. Available: http://www.ashanet.org/focusgroups/ sanctuary/articles/ReportonTrafficking.pdf. Accessed 1 October 2007.

4. Silverman JG, Decker MR, Gupta J, Maheshwari A, Willis BM, et al. (2007) HIV prevalence and predictors of infection in sex-trafficked Nepalese girls and women. JAMA 298: 536-542.

5. Farley M, Barkan H (1998) Prostitution, violence and posttraumatic stress disorder. Women Health 27: 37-49.

6. Gangopadhyay DN, Chanda M, Sarkar K, Niyogi SK, Chakraborty $\mathrm{S}$, et al. (2005) Evaluation of sexually transmitted diseases/human immunodeficiency virus intervention programs for sex workers in Calcutta, India. Sex Transm Dis 32: 680-684.

7. Busza J, Baker (2004) Protection and participation: An interactive programme introducing the female condom to migrant sex workers in Cambodia. AIDS Care 16: 507-518.

Citation: Silverman J, Decker M (2007) The US anti-prostitution pledge: A call for cooperation. PLoS Med 4(10): e280. doi:10.1371/journal.pmed.0040280

Copyright: $\odot 2007$ Silverman and Decker. This is an open-access article distributed under the terms of the Creative Commons Attribution License, which permits unrestricted use, distribution, and reproduction in any medium, provided the original author and source are credited.

Funding: The authors received no specific funding for this article.

Competing Interests: The authors have declared that no competing interests exist.

\section{The US Anti-Prostitution Pledge: Authors' Reply}

We would like to thank Jay Silverman and Michele Decker for their thoughtful contribution to the public health discussion regarding commercial sex work and the grave issues of child prostitution and sex trafficking [1]. As the correspondents rightly assert, trafficking in persons is a criminal and human rights offense and should be vigorously opposed and its victims provided services. This is not a domain of any real contention in the public health or human rights communities. Nevertheless, the conflation of all forms of sex work with human trafficking, which they contend is an outcome of the essential inseparability of these two phenomena, does remain contentious. And, as with our paper, their work does not, arguably, resolve this contention. For the population of consenting adults who sell sex of their own volition, in settings as divergent from the India-Nepal context where Silverman et al. have worked as Washington D. C. or Amsterdam, sex workers and their advocates claim a domain of prevention and engagement that also uses human rights language, albeit the language of workers' rights and empowerment, to argue for services. And there is ample evidence to suggest that empowerment and an end to police harassment can improve health outcomes, including HIV.

It may be that the most important issues in sex work and sex trafficking are contextual. In Silverman and Decker's recent work, funded by the Office to Monitor and Combat Trafficking in Persons of the Bush Administration's Department of State, they reviewed medical documentation 
and case record materials for 287 sex-trafficked and repatriated Nepalese girls and women who received services at Maiti Nepal between January 1997 and December 2005. Their findings revealed that $109(38.0 \%)$ women and girls were HIV positive [2]. In our own work, perhaps $60 \%$ of ethnic Shan women living in Burma who were trafficked to Thailand may be HIV infected [3]. In both these Asian communities, the contexts of poverty (Nepal and Burma relative to India and Thailand, respectively) and the very low status both of women and girls and illegal aliens more generally, makes it almost impossible for any sex work not to be profoundly exploitative.

In contrast, our work with AIDS service organizations in Moscow, Russia has taken place in a markedly different context [4]. The majority of women we encountered were adults when entering sex work, and over $80 \%$ indicated willingly entering into sex work and even coming to Moscow seeking such work. High rates of unemployment among women in the former Soviet Union, due to economic depression and gender discrimination, have brought these women to the Moscow sex trade seeking income. These economic factors are compounded by the fact that the majority of women in our sample were financially assisting or fully supporting family members. The fact that people besides themselves were dependent on the income of many of the sex workers must be taken into consideration in programs aimed at cessation of sex work. But none of the women interviewed were Moscow residents before entering the Moscow sex industry. Lack of legal status is perhaps the largest barrier preventing sex workers from receiving many important services and social benefits such as free and anonymous medical treatment, a steady job (outside of sex work), protection from the police, lodging, and psychological assistance. This is not a function of the legality of prostitution (sex work is not illegal in the Russian Federation), but of not having legal residency.

This example illustrates the highly contextual nature of sex work, and indeed, of trafficking, and perhaps argues against a "one size fits all" approach to these difficult problems.

\section{Chris Beyrer}

Nicole Masenior (nfranck@jhsph.edu)

Johns Hopkins Bloomberg School of Public Health

Baltimore, Maryland, United States of America

\section{References}

1. Silverman J, Decker M (2007) The US anti-prostitution pledge: A call for cooperation. PLoS Med 4: e280. doi:10.1371/journal.pmed.0040280

2. Silverman JG, Decker MR, Gupta J, Maheshwari A, Willis BM, et al. (2007) HIV prevalence and predictors of infection in sex-trafficked Nepalese girls and women. JAMA 298: 536-542.

3. Beyrer C (2001) Shan women and girls and the sex industry in Southeast Asia; Political causes and human rights implications. Soc Sci Med 53: 543-550.

4. Stachowiak J, Sherman S, Konakova A, Krushkova I, Beyrer C (2005) Health risks and power among sex workers in Moscow. SEICUS Report 33: 18-25.

Citation: Beyrer C, Masenior N (2007) The US anti-prostitution pledge: Authors' reply. PLoS Med 4(10): e318. doi:10.1371/journal.pmed.0040318

Copyright: $\odot 2007$ Beyrer and Masenior. This is an open-access article distributed under the terms of the Creative Commons Attribution License, which permits unrestricted use, distribution, and reproduction in any medium, provided the original author and source are credited.

Funding: The authors received no specific funding for this article.

Competing Interests: The authors have declared that no competing interests exist.

\section{Tobacco Substitutes: Snus and}

\section{Harm Reduction}

\section{Maia Szalavitz}

How can you even have a debate over whether to publish data on snus [1]? No medical journal even contemplated not publishing data on needle exchange to prevent HIV-which continues addiction just as surely as snus does, while similarly producing a dramatic reduction in the risk of death. Journals don't censor data on nicotine replacement or methadone maintenance or buprenorphine or even heroin maintenance, which continue physical dependence if not always addiction. They even publish data on amphetamine maintenance!

What kind of bizarre political correctness would even suggest not publishing data that could show whether snus improves or harms health? You may want to debate whether or not tobacco should be advertised, whether or not the industry should be banned and replaced by government control of nicotine delivery-devices, even whether tobacco should be prohibited entirely. But not publish data on what appears to be from existing data an amazingly successful public health intervention? What kind of a "public library of science" would even contemplate that?

Maia Szalavitz (maiasz@gmail.com)

Statistical Assessment Service

New York, New York, United States of America

References

1. The PLoS Medicine Editors (2007) Tobacco substitutes: Harm reduction or smokescreen? PLoS Med 4: e244. doi:10.1371/journal.pmed.0040244

Citation: Szalavitz M (2007) Tobacco substitutes: Snus and harm reduction. PLoS Med 4(10): e282. doi:10.1371/journal.pmed.0040282

Copyright: $\odot 2007$ Maia Szalavitz. This is an open-access article distributed under the terms of the Creative Commons Attribution License, which permits unrestricted use, distribution, and reproduction in any medium, provided the original author and source are credited.

Funding: The author received no specific funding for this article.

Competing Interests: The author has declared that no competing interests exist.

\section{Should the Health Community} Promote Smokeless Tobacco (Snus): Comments from British American Tobacco

\section{Justine Williamson, Christopher Proctor}

Chapman and Freeman question the tobacco industry's aims on snus, and whether these aims can be consistent with harm reduction [1]. We cannot speak on behalf of the industry as a whole. However, we at British American Tobacco understand that cigarette smoking is a major cause of serious and fatal diseases, and we believe that the use of Swedish-style snus products, while not harmless, is substantially less harmful than cigarette smoking [2]. We are piloting snus in several countries outside of Sweden as a response to those public health stakeholders who have told us they believe that snus, properly regulated, can contribute to reducing the net public health impact of tobacco use.

We believe adult consumers of tobacco products would benefit from the enactment of a regulatory framework 
that facilitates consistent, accurate, and meaningful communications on the relative health risks of smoking, using snus, or abstaining entirely from tobacco use. While ideally this framework would be developed and agreed upon under the Framework Convention for Tobacco Control, the recent second Conference of the Parties to the Framework Convention did not address oral tobacco products and has not assigned a high priority to tobacco product regulation in this area. Given this, we think national governments should develop a regulatory framework for snus. In doing so, we think that governments should be mindful of the concerns expressed by Chapman and Freeman.

We agree with the recently released preliminary report from the European Union's Scientific Committee on Emerging and Newly Identified Health Risks, which states that "the balance of these effects [beneficial versus adverse effects on smoking prevalence] will be highly dependent upon the marketing of the product, the health messages delivered with it, and the extent to which switching to smokeless tobacco products as a harm reduction strategy is endorsed by health professionals and their organisations" [3].

We acknowledge that some have concerns with regard to our interest in snus as a less harmful alternative to cigarettes. We seek to work with the public health community and regulators to achieve a reduction in the public health impact of tobacco use.

\section{Justine Williamson (justine_williamson@bat.com)}

\section{Christopher Proctor \\ British American Tobacco \\ London, United Kingdom}

\section{References}

1. Gartner CE, Hall WD, Chapman S, Freeman B (2007) Should the health community promote smokeless tobacco (snus) as a harm reduction measure? PLoS Med 4: e185. doi:10.1371/journal.pmed.0040185

2. Levy DT, Mumford EA, Cummings KM, Gilpin EA, Giovino G, et al. (2004) The relative risks of a low-nitrosamine smokeless tobacco product compared with smoking cigarettes: Estimates of a panel of experts. Cancer Epidemiol Biomarkers Prev 13: 2035-2042.

3. Scientific Committee on Emerging and Newly Identified Health Risks (2007) Health effects of smokeless tobacco products: Preliminary report. Available: http://ec.europa.eu/health/ph_risk/committees/04_scenihr/ docs/scenihr_o_009.pdf. Accessed 1 October 2007.

Citation: Williamson J, Proctor C (2007) Should the health community promote smokeless tobacco (snus): Comments from British American Tobacco. PLoS Med 4(10): e300. doi:10.1371/journal.pmed.0040300

Copyright: $\odot 2007$ Williamson and Proctor. This is an open-access article distributed under the terms of the Creative Commons Attribution License, which permits unrestricted use, distribution, and reproduction in any medium, provided the original author and source are credited.

Funding: The authors received no specific funding for this article.

Competing Interests: The authors have declared that no competing interests exist.

\section{Should the Health Community Promote Smokeless Tobacco (Snus): Author's Reply}

As someone who has researched and advocated for harm reduction in the HIV/AIDS [1] and narcotics areas [2], I am highly supportive of the general principle of reducing harm in public health. My recently released book [3] features a 29,000 word chapter examining the application of the term in tobacco control. My current position is that there is an overly seductive simplicity in drawing neat analogies with other areas of harm reduction when it comes to tobacco. It is obvious that there is immediate benefit to health and society from encouraging condom use and clean needle use. However, the putative benefits of population experiments with harm reduction will not be assessable for 30-40 years.

Behind most calls for harm reduction in tobacco control policy lie under-examined assumptions that there is a large intractable smoking population for whom cessation is "an impossible goal," as Maggie Brown puts it [4]. In New South Wales, Australia where I live, only $13.9 \%$ of people aged 14 and over now smoke daily. In recent years smoking prevalence has been falling faster than at any time in the past. There is poor evidence for the "hardening" hypothesis, with $29 \%$ of smokers now describing themselves as only occasional smokers and daily consumption falling [5], facts incompatible with hardening. Around $75 \%$ of smokers say they wish to quit, and only about $3.5 \%$ of smokers say they want to continue using tobacco. It is a fraction of this group that harm reduction advocates seek to interest.

While a case may exist for carefully controlled access to snus by such a relatively small group, the case for allowing the foxes in the tobacco industry into the chicken coop of open sales and marketing should alarm anyone with their eyes open to the industry's bottom line. Recent insights confirm our caution that Big Tobacco sees snus as a way of arresting declines in smoking by promoting dual use. Citigroup, the investment advisors, are very clear on the way snus will be marketed and used, writing "Over $60 \%$ of our survey respondents [in the tobacco trade] do not believe snus products will have an impact on cig volumes. The trade believes that snus will be consumed in addition to cigarettes. Given the increased bans on smoking, snus products seem like an obvious substitution" [6]. This was echoed in the US retail trade newsletter Brandweek: "There's money to be made from municipal smoking bans as another cigarette maker chases after smokers who get their nicotine fix between their cheek and gum during those many moments when they can't light up" [7].

I'm certain that your British American Tobacco correspondents [8] "understand" that cigarettes cause disease, as they put it. That being the case, might we anticipate British American Tobacco planning to end sales of its cigarettes in the areas in which it is test marketing samename brand snus? Does it plan to run aggressive, effective, graphic advertising campaigns on the dangers of smoking its cigarettes?

\section{Simon Chapman (simonchapman@health.usyd.edu.au) University of Sydney}

Sydney, New South Wales, Australia

\section{References}

1. Chapman S, Hodgson J (1988) Showers in raincoats: Attitudinal barriers to condom use in high risk heterosexuals. Community Health Stud 12: 97-105.

2. Lawrence G, Bammer G, Chapman S (2000) "Sending the wrong signal": Analysis of print media reportage of the ACT heroin prescription proposal, August 1997. Aust NZ J Public Health 24: 254-264.

3. Chapman S (2007) Public health advocacy and tobacco control: Making smoking history. Oxford: Blackwell.

4. Brown M (2007) Is it about tobacco or about harm reduction? PLoS Medicine reader response. Available: http://medicine.plosjournals.org/ perlserv/?request=read-response\&amp;doi=10.1371/journal.pmed.0040185. Accessed 1 October 2007.

5. Morley KI, Hall WD, Hausdorf K, Owen N (2006) 'Occasional' and 'social' smokers: Potential target groups for smoking cessation campaigns? Aust NZ J Public Health 30: 550-554.

6. Herzog B (2007) Industry in-depth. Tobacco. Citigroup.

7. Beirne M (2007) Philip Morris expands smokeless tobacco line. Brandweek. com. Available: http://www.brandweek.com/bw/news/recent_display. jsp?vnu_content_id=1003597188. Accessed 1 October 2007. 
8. Williamson J, Proctor C (2007) Should the health community promote smokeless tobacco (snus): Comments from British American Tobacco. PLoS Med 4: e300. doi:10.1371/journal.pmed.0040300

Citation: Chapman S (2007) Should the health community promote smokeless tobacco (snus): Author's reply. PLoS Med 4(10): e299. doi:10.1371/journal. pmed.0040299
Copyright: $\odot 2007$ Simon Chapman. This is an open-access article distributed under the terms of the Creative Commons Attribution License, which permits unrestricted use, distribution, and reproduction in any medium, provided the original author and source are credited.

Funding: The author received no specific funding for this article.

Competing Interests: The author has declared that no competing interests exist. 